\title{
Effects of Climate Change on the Yield and Cropping Area of Major Food Crops: A Case of Bangladesh
}

\author{
Md. Ruhul Amin ${ }^{1,2, \dagger}$, Junbiao Zhang ${ }^{1, \dagger, *}$ and Mingmei Yang ${ }^{1}$ \\ 1 College of Economics and Management, Huazhong Agricultural University, Wuhan 430070, China; \\ E-Mails: ruhulext_ru@yahoo.com (M.R.A.); yangmm51@mail.hzau.edu.cn (M.Y.) \\ 2 Department of Agronomy and Agricultural Extension, University of Rajshahi, \\ Rajshahi 6205, Bangladesh
}

$\uparrow$ These authors contributed equally to this work.

* Author to whom correspondence should be addressed; E-Mail: zhangjunbiao@mail.hzau.edu.cn; Tel.: +86-27-8728-8381; Fax: +86-27-8728-2973.

Academic Editor: Giuseppe Ioppolo

Received: 10 November 2014 / Accepted: 8 January 2015 / Published: 14 January 2015

\begin{abstract}
The crops that we grow for food need specific climatic conditions to show better performance in view of economic yield. A changing climate could have both beneficial and harmful effects on crops. Keeping the above view in mind, this study is undertaken to investigate the impacts of climate change (viz. changes in maximum temperature, minimum temperature, rainfall, humidity and sunshine) on the yield and cropping area of four major food crops (viz. Aus rice, Aman rice, Boro rice and wheat) in Bangladesh. Heteroskedasticity and autocorrelation consistent standard error (HAC) and feasible generalized least square (FGLS) methods were used to determine the climate-crop interrelations using national level time series data for the period of 1972-2010. Findings revealed that the effects of all the climate variables have had significant contributions to the yield and cropping area of major food crops with distinct variation among them. Maximum temperature statistically significantly affected all the food crops' yield except Aus rice. Maximum temperature also insignificantly affected cropping area of all the crops. Minimum temperature insignificantly affected Aman rice but benefited other three crops' yield and cropping area. Rainfall significantly benefitted cropping area of Aus rice, but significantly affected both yield and cropping area of Aman rice. Humidity statistically positively contributed to the yield of Aus and Aman rice but, statistically, negatively influenced the cropping area of Aus rice. Sunshine statistically significantly benefitted only
\end{abstract}


Boro rice yield. Overall, maximum temperature adversely affected yield and cropping area of all the major food crops and rainfall severely affected Aman rice only. Concerning the issue of climate change and ensuring food security, the respective authorities thus should give considerable attention to the generation, development and extension of drought (all major food crops) and flood (particularly Aman rice) tolerant varieties.

Keywords: Bangladesh; climate change; yield and cropping area; major food crops; food security; drought; flood; sustainable agricultural development

\section{Introduction}

The effects of climate change on crop production are international concerns, but they are particularly significant for the sustainable agricultural development of Bangladesh [1]. This is a country of variant climatic conditions year-round due to its geographic position and physiographic status. The biggest mountain Himalayas in the north and the funnel-shaped Bay of Bengal in the south have made Bangladesh a meeting point of the life-long monsoon precipitations and the catastrophic devastation of floods, droughts, cyclones, storm surges, etc. [2]. Agriculture is always susceptible to unfavorable weather conditions and climate events. In spite of technological progress (such as improved crop varieties and irrigation potentialities), weather and climate are still key determinants for agricultural productivity and sustainability. Agriculture in Bangladesh is already under pressure, both from huge and increasing demands for food as well as from obstacles related to the degradation of agricultural land and water endowments [3]. Any internal and external threat (social, political, natural and environmental) to agriculture directly affects food grain production as well as food security of the country [4]. Sometimes the relation between these key factors and production losses are obvious, but often the relations are less direct. In spite of the recent strides regarding gaining sustainable development, Bangladesh's ability to restore its development is experienced with significant challenges and confounded by climate change [5].

Bangladesh has been facing higher temperatures over the last three decades [6]. Moreover, it is forecasted to experience a rise in annual mean temperatures of $1.0^{\circ} \mathrm{C}$ by $2030,1.4{ }^{\circ} \mathrm{C}$ by 2050 and $2.4{ }^{\circ} \mathrm{C}$ by 2100 . The prediction for the winter season (December, January and February) average temperature also showed a similar increasing pattern, $1.1{ }^{\circ} \mathrm{C}$ by $2030,1.6{ }^{\circ} \mathrm{C}$ by 2050 and $2.7{ }^{\circ} \mathrm{C}$ by 2100. The projected value is $0.8^{\circ} \mathrm{C}$ by $2030,1.1^{\circ} \mathrm{C}$ by 2050 and $1.9{ }^{\circ} \mathrm{C}$ by 2100 for the monsoon months [7,8]. However, the Global Climate Model (GCM) data estimated more warming for winter than for the summer months [9]. Based on the above projections, Bangladesh is likely to face more hot days and heat waves, longer dry spells and higher drought risk. In contrast, almost 80 percent of rainfalls in Bangladesh have been occurring during monsoon season (June-September). The remaining 20 percent covers eight months, including the winter months in which the high-yielding rice Boro is grown. Though monsoon season's rainfall is projected to increase; the rainfall variability may increase significantly causing more intense rainfall and/or longer dry spells. Most of the climate models estimated that precipitation will increase during the summer monsoon [10-12]. This erratic and unevenly distributed pattern produces extreme events, such as floods and droughts, which have 
remarkable harmful effects on major food crops' yield, especially on Aman rice. As a result, rice production is likely to decline by $8 \%-17 \%$ by $2050[6,13,14]$. It is noticed that Aman rice had dominated in Bangladesh from 1980-1981 and contributed to 57\% of the total share. However, due to drought and flood events, the trend of share of Aman rice to the total rice production decreased to $40 \%$ by 2005-2006, even though the total cultivated area devoted to this crop is much higher than others to date [4].

Food security is defined as access to enough and safe food by all people at all times for maintaining an active and healthy life. Bangladesh is predominantly an agrarian country with a high population density, where food security is a crucial issue. However, aggregate domestic production and per capita availability of food grains have increased in the country over the past decades. Nonetheless, the country still depends on import of food grains [4]. In 2007-2008, it imported 11.5 percent of total availability and it is predicted that until 2021, the annual requirement for staple food will also exceed supply, indicating that demand is higher than production [15]. Thus, it needs to increase the rice and wheat yield in order to fulfill the growing demand for food emanating from population growth. Climate change is a potential threat towards achieving the above mentioned objective. It is therefore necessary to realize the effects of climate change on the production of major food crops under sustainable environmental conditions [16]. Examination of climatology at the national level is most important for the remedy of agricultural problems arising from climate change. Climatic information not only recommends the most suitable time for sowing and harvesting but also acts as a guide to the selection of the proper sites for a certain crop [17]. Historically, most of the past studies regarding climate change impacts have concentrated on US outcomes [18,19]. Interestingly, recent work has increasingly studied the impacts of climate change on agricultural production in the developing nations (such as Asia and Africa) [20-25]. However, all of these studies have demonstrated that agricultural activities in developing countries are extremely vulnerable to climate change.

Despite the status of Bangladesh as a country that is greatly sensitive to climate change, factual studies of the significance of climate change on major food crops in this country have been scarce [26]. The study of climate change impacts on Bangladesh agriculture has achieved recent attention, due to the share of Bangladesh's agricultural sector. Rimi et al. [27] have conducted a study on the trend and prediction of future climate change scenarios with GCMs, most purposively investigating the impacts of climate change on rice production. They found that temperature variations had spectacular implications on crop yield. The summer crop Aus production has decreased significantly. The production of Boro rice, a winter crop, has increased significantly with the increase of minimum temperature. The inter-annual fluctuation in the amount of winter season rainfall was little. Boro production, therefore, was insignificantly affected by this variable. However, correlation between the climatic variables and crop production was not statistically significant. In most situations, they found that irrespective of crops and GCMs, climate change would have an adverse effect. However, their study simulated the future scenarios of a specific region and specific crop (confined to Satkhira district and rice crop only). Awal and Siddique [28] estimated the trend of rice production by employing ARIMA model but did not consider climate influence. Hossain and Teixeira da Silva [1] have undertaken an initiative to document the climate change impact on rice and wheat yield in Bangladesh. Their study has drawn a conclusion that global warming is expected to severely reduce the yield of various crops, including rice and wheat, directly affecting the food security of 165 million people in Bangladesh. However, this study only reviewed the past studies. Sarker [29] carried out a study to examine the 
relationship between three climate variables (maximum temperature, minimum temperature and rainfall) and three rice crops. He considered 1971-1972 fiscal years' yield as the yield of 1972. However, to ensure consistency between climate parameters and yield, he accounted 1972's climate for 1972's yield. Actually, the previous (1971) year's climate data should be calculated for Aus and Aman rice as their growing season completely fell in this year. In case of calculating climate data for Boro rice, it should merge two calendar years into one (for example, from December of 1971 to May of 1972 for 1972's yield), as he considered the growing months for Boro rice to be December-May. That is why his study might not represent the real relation between climate change and crops yield. In addition, he did not consider humidity and sunshine as climate variables although these variables have significant influence on crop production. Furthermore, to explain climate change impacts, he considered only rice in terms of the climate parameters, and did not pay attention to wheat.

Few studies have been done in Bangladesh to investigate the pattern and trend of rainfall, temperature, solar radiation, relative humidity, heat budget and energy balance on various ecosystem, and meteorological application on rice production, response of weather on wheat yield. However, previous records show that very few of them have intensively examined the relationship between climate change and crop production [2]. Consequently, these studies might have generated deceptive findings owing to misinterpretation. Moreover, different crops might be affected non-uniformly [21]. Accordingly, crop-oriented research (particularly on major staples) is pledged to formulate better policy suggestions for sustainable development. Therefore, the purpose of this study is to analyze the nexus between climate change and yield as well as cropping area of major food crops in Bangladesh using national level time series data over the span from 1972 to 2010.

\section{Climatic Features of Major Food Crops in Bangladesh}

Three rice crops (Aus, Aman and Boro) and wheat are the major food crops in Bangladesh. These are grown in different distinct seasons. Aus is generally sown/grown in March-April and harvested in July-August. Aman is normally planted in June-August and harvested in November-December. Boro is transplanted in December-January and harvested in April-May. Finally, wheat is sown in November-December and harvested in March-April [29-31]. To some extent, the calendar for these major crops differs marginally from place to place, regulated by edaphic and climatic conditions. Surprisingly, these growing periods are also essentially matched with three climatic periods, for example, the hot summer (March-May), the monsoon (July-October) and the winter (December-February). According to BRRI (1991), Aus rice demands supplementary water at the initial stage of its growing season while Aman is completely rain-fed rice that grows in the months of monsoon, though it requires supplementary irrigation at the transplanting and occasionally at the flowering stage subject to the availability of precipitation. Boro is the fully irrigated rice as it grows in the dry winter and the hot summer [32]. Finally, wheat is also a winter crop as it grows in the winter months under mostly rain-fed conditions. 


\section{Methodology}

\subsection{Data Sources and Properties}

National level yield data of major food crops (Aus rice, Aman rice, Boro rice and wheat) in the time span 1972-2010 were collected from various versions of the yearbook of agricultural statistics in Bangladesh [33]. Yield data were found as the fiscal year basis, such as 1971-1972, 1972-1973, etc. Then, these fiscal year data were converted to yearly data, for example, 1971-1972 was considered as 1972. Aggregate level monthly data on climatic parameters for all (32) the weather stations was procured from the Bangladesh Meteorological Department (BMD) [34] for the same time period, which covers the whole country. These year-wise monthly data were then transformed to seasonal data according to the growing period of the crops. In case of Aus and Aman rice, as the length of growing season varies from March-August and June-November respectively, climatic variables have been defined for this total time period. However, the growing period for Boro rice and wheat has been counted from December-May and November-April respectively. Generally, the life span average has been taken into consideration for all the climatic parameters except for rainfall. Production period total has been calculated for rainfall. As a result, the study came to the point that, in order to make a consistency between climatic variables and yield (as well as cropping area) data, 1971's climate data were used against 1972's yield and cropping area particularly for Aus and Aman rice. Similarly, the previous year (1971) and next year (1972) climate data were merged for 1972's yield and cropping area for Boro and wheat, as these two crops' growing period is distributed into two calendar years.

\subsection{Descriptive Statistics}

The descriptive statistics were presented in Table 1, which delineates the basic properties of all the variables under study. In case of yield, it was found that, among the four major crops, the mean yield of Boro rice was the highest and it was two times higher than that of Aus rice. The observed mean yield of the four crops under study according to the descending order was as follows: Boro > wheat > Aman $>$ Aus. In view of average (mean) cropping area and production, Aman rice ranked the highest position and wheat ranked the lowest. Boro and Aus rice stood second and third place in respect of average cropping area and production respectively. In case of climate variables, the highest maximum temperature was noticed in the Aus growing season and the highest minimum temperature were monitored in the Aman growing season. In contrast, the lowest maximum and minimum temperature was observed in the wheat season. In the case of rainfall, wheat received the lowest total rainfall, whereas Aus and Aman received more than seven times than that of wheat's growing season. However, the highest rainfall was observed in the Aman rice growing season followed by the Aus rice season. In view of humidity, the highest percentage of humidity was detected in the Aman season, but the lowest value was detected in the wheat growing season. Finally, highest sunshine was observed in the wheat growing season and lowest was seen in the Aman season. 
Table 1. Descriptive statistics, 1972-2010.

\begin{tabular}{|c|c|c|c|c|c|c|c|}
\hline \multirow[t]{2}{*}{ Variables } & \multirow{2}{*}{$\begin{array}{l}\text { Major } \\
\text { Crops }\end{array}$} & \multicolumn{6}{|c|}{ Statistics } \\
\hline & & Mean & Std. dev. & Min. & Max. & Skewness & Kurtosis \\
\hline \multirow{4}{*}{$\begin{array}{l}\text { Cropping area } \\
\text { ('000 ha) }\end{array}$} & Aus & 2174.49 & 882.37 & 906.40 & 3422.01 & -0.05 & 1.33 \\
\hline & Aman & 5709.70 & 343.36 & 5050.11 & 7181.51 & 1.66 & 10.14 \\
\hline & Boro & 2479.74 & 1253.25 & 855.04 & 4718.35 & 0.31 & 1.74 \\
\hline & Wheat & 509.63 & 216.31 & 119.78 & 882.45 & -0.51 & 2.31 \\
\hline \multirow{4}{*}{$\begin{array}{l}\text { Production } \\
\text { ('000 tons) }\end{array}$} & Aus & 2349.16 & 612.29 & 1500.47 & 3287.94 & 0.17 & 1.46 \\
\hline & Aman & 8740.37 & 1738.29 & 5586.56 & $12,207.16$ & 0.13 & 2.13 \\
\hline & Boro & 7232.98 & 5044.70 & 1650.13 & $18,058.96$ & 0.75 & 2.38 \\
\hline & Wheat & 985.34 & 495.34 & 90.00 & 1908.44 & -0.22 & 2.49 \\
\hline \multirow{4}{*}{$\begin{array}{c}\text { Yield } \\
\text { (kg/acre) }\end{array}$} & Aus & 475 & 111 & 314 & 720 & 0.81 & 2.56 \\
\hline & Aman & 622 & 132 & 396 & 872 & 0.29 & 1.94 \\
\hline & Boro & 1072 & 229 & 737 & 1560 & 0.64 & 2.44 \\
\hline & Wheat & 736 & 160 & 303 & 970 & -1.29 & 4.22 \\
\hline \multirow{4}{*}{$\begin{array}{c}\text { Maximum } \\
\text { temperature }\left({ }^{\circ} \mathrm{C}\right)\end{array}$} & Aus & 32.04 & 0.44 & 31.15 & 33.04 & -0.06 & 2.44 \\
\hline & Aman & 31.18 & 0.37 & 30.47 & 32.04 & 0.23 & 2.70 \\
\hline & Boro & 29.6 & 0.54 & 28.58 & 30.82 & 0.08 & 2.63 \\
\hline & Wheat & 29.03 & 0.54 & 28.08 & 30.53 & 0.39 & 3.08 \\
\hline \multirow{4}{*}{$\begin{array}{c}\text { Minimum } \\
\text { temperature }\left({ }^{\circ} \mathrm{C}\right)\end{array}$} & Aus & 24.03 & 0.35 & 23.34 & 24.62 & -0.32 & 2.22 \\
\hline & Aman & 24.17 & 0.3 & 23.50 & 25.13 & 0.57 & 4.27 \\
\hline & Boro & 18.26 & 0.42 & 17.49 & 19.10 & 0.22 & 2.49 \\
\hline & Wheat & 17.37 & 0.43 & 16.66 & 18.48 & 0.45 & 2.62 \\
\hline \multirow{4}{*}{$\begin{array}{l}\text { Rainfall } \\
\text { (mm/year) }\end{array}$} & Aus & 9308 & 1520 & 5559 & 11579 & -0.54 & 2.50 \\
\hline & Aman & 9811 & 1587 & 5642 & 12811 & -0.28 & 2.73 \\
\hline & Boro & 2436 & 728 & 942 & 3912 & 0.27 & 2.51 \\
\hline & Wheat & 1236 & 516 & 459 & 2162 & 0.25 & 1.91 \\
\hline \multirow{4}{*}{ Humidity (\%) } & Aus & 80.51 & 1.49 & 76.99 & 82.88 & -0.21 & 2.15 \\
\hline & Aman & 84.36 & 1.13 & 81.92 & 86.32 & -0.35 & 2.31 \\
\hline & Boro & 74.63 & 2.47 & 69.47 & 79.01 & -0.2 & 1.94 \\
\hline & Wheat & 74.49 & 2.57 & 69.92 & 78.71 & -0.15 & 1.71 \\
\hline \multirow{4}{*}{$\begin{array}{l}\text { Sunshine } \\
\text { (hours/day) }\end{array}$} & Aus & 5.98 & 0.41 & 5.35 & 7.10 & 0.93 & 3.51 \\
\hline & Aman & 5.44 & 0.37 & 4.65 & 6.37 & 0.42 & 3.03 \\
\hline & Boro & 7.69 & 0.64 & 6.73 & 9.11 & 0.86 & 2.93 \\
\hline & Wheat & 7.83 & 0.63 & 6.81 & 9.23 & 0.69 & 2.86 \\
\hline
\end{tabular}

Source: Authors' own estimation based on GOB (2012) and BMD (2013).

\subsection{Analysis of Quantitative Linear Trend in Climatic Variables}

It is obviously true that the above descriptive statistics could not reflect climate change and variability among climate parameters. Therefore, further verification was done to observe exact trends in climatic variables by estimating linear trend model with time $(\mathrm{t})$ as an explanatory factor over the whole period. The results of the linear trend model of changes in climatic parameters were displayed in Table 2. Both t-values and p-values revealed that most of the climate variables showed noticeable significance of trend. However, the significance of trend for maximum temperature was the largest for the Aman rice and the smallest for wheat. With the perspective of the minimum temperature, 
the significance of trend was highest for the Boro rice and lowest for the Aman rice. With regard to the rainfall, the maximum significance of trend was seen in the case of the Aman rice growing period and minimum were seen in the Aus season. Humidity showed the highest significance of trend in the Aus, Boro and wheat season, but lowest in the Aman season. Sunshine expressed maximum significance of trend in Aman, Boro and wheat growing period, but minimum significance of trend in the Aus season. However, empirical findings displayed that, maximum temperature, minimum temperature, rainfall (particularly in the Aus and Aman rice growing season) and humidity appeared to show an upward (increasing) trend over the entire period, 1972-2010. In contrast, sunshine demonstrated a downward (decreasing) trend for all the major crop growing periods. These pictures provided clear evidence of changing climate across the four major food crops growing seasons in Bangladesh. We have estimated whether this potential climate change affected major food crops yield and their cropping area later.

Table 2. The results of the linear trend model of changes in climate parameters, 1972-2010.

\begin{tabular}{|c|c|c|c|c|c|c|}
\hline Crops & Climate Parameters & Intercept & Coefficient for Time (Trend) & $t$-value & $p$-value & $R^{2}$ \\
\hline \multirow{5}{*}{ Aus Rice } & Maxt & -5.78 & $0.02 * * *$ & 3.41 & 0.002 & 0.24 \\
\hline & Mint & -5.21 & $0.01 * * *$ & 3.35 & 0.002 & 0.23 \\
\hline & Rainfall & $-117,984.50$ & $63.93 * * *$ & 3.32 & 0.002 & 0.23 \\
\hline & Humidity & -61.44 & $0.07 * * *$ & 3.95 & 0.000 & 0.30 \\
\hline & Sunshine & 42.41 & $-0.02 * * *$ & -3.58 & 0.001 & 0.26 \\
\hline \multirow{5}{*}{ Aman Rice } & Maxt & -12.88 & $0.02 * * *$ & 5.76 & 0.000 & 0.47 \\
\hline & Mint & 8.55 & $0.01 *$ & 1.90 & 0.065 & 0.09 \\
\hline & Rainfall & $-176,815$ & $93.73 * * *$ & 5.54 & 0.000 & 0.45 \\
\hline & Humidity & -19.76 & $0.05 * * *$ & 3.76 & 0.001 & 0.28 \\
\hline & Sunshine & 45.86 & $-0.02 * * *$ & -4.91 & 0.000 & 0.39 \\
\hline \multirow{5}{*}{ Boro Rice } & Maxt & 0.60 & $0.01 *$ & 1.98 & 0.055 & 0.10 \\
\hline & Mint & -19.80 & $0.02 * * *$ & 3.75 & 0.001 & 0.28 \\
\hline & Rainfall & -9587 & 6.04 & 0.58 & 0.567 & 0.01 \\
\hline & Humidity & -231.79 & $0.15 * * *$ & 6.13 & 0.000 & 0.50 \\
\hline & Sunshine & 90.47 & $-0.04 * * *$ & -6.82 & 0.000 & 0.56 \\
\hline \multirow{5}{*}{ Wheat } & Maxt & 3.11 & $0.01 *$ & 1.73 & 0.092 & 0.08 \\
\hline & Mint & -16.06 & $0.02 * * *$ & 3.02 & 0.005 & 0.20 \\
\hline & Rainfall & 6899 & -2.84 & -0.38 & 0.704 & 0.01 \\
\hline & Humidity & -256.11 & $0.17 * * *$ & 6.61 & 0.000 & 0.54 \\
\hline & Sunshine & 91.72 & $-0.04 * * *$ & -7.21 & 0.000 & 0.58 \\
\hline
\end{tabular}

$*$ and $* * *$ represents the $10 \%$ and $1 \%$ level of significance respectively. Maxt $=$ growing season average daily maximum temperature. Mint = growing season average daily minimum temperature.

\subsection{Trend Graph}

In addition to examining descriptive statistics and analyzing linear trend between time and climatic variables, graphs were also constructed with time (t) as an explanatory variable to observe the spectacular impression about the variations and changes in trend (upward or downward) among the five climatic variables over the whole period (1972-2010) (Figures 1-5). Maximum temperature fluctuated greatly, but the overall trend was observed to increase for all the seasons (Figure 1). Small variations were noticed in minimum temperature; however, the trend still appeared to be increasing 
(Figure 2). Rainfall in the Aus and Aman rice growing seasons showed upward trends with distinct and greatest fluctuations. The Boro rice and wheat season did not reveal any distinct trend over time, but the variations would be seriously affected these two crops (Figure 3). Humidity also demonstrated an increasing trend with minor deviations (Figure 4). Interestingly, sunshine exhibited a decreasing (downward) trend for all the seasons with greater fluctuations (Figure 5). However, investigation was done to confirm whether these climatic trends and fluctuations affected crops yield in the later section.

The trend of Maxt

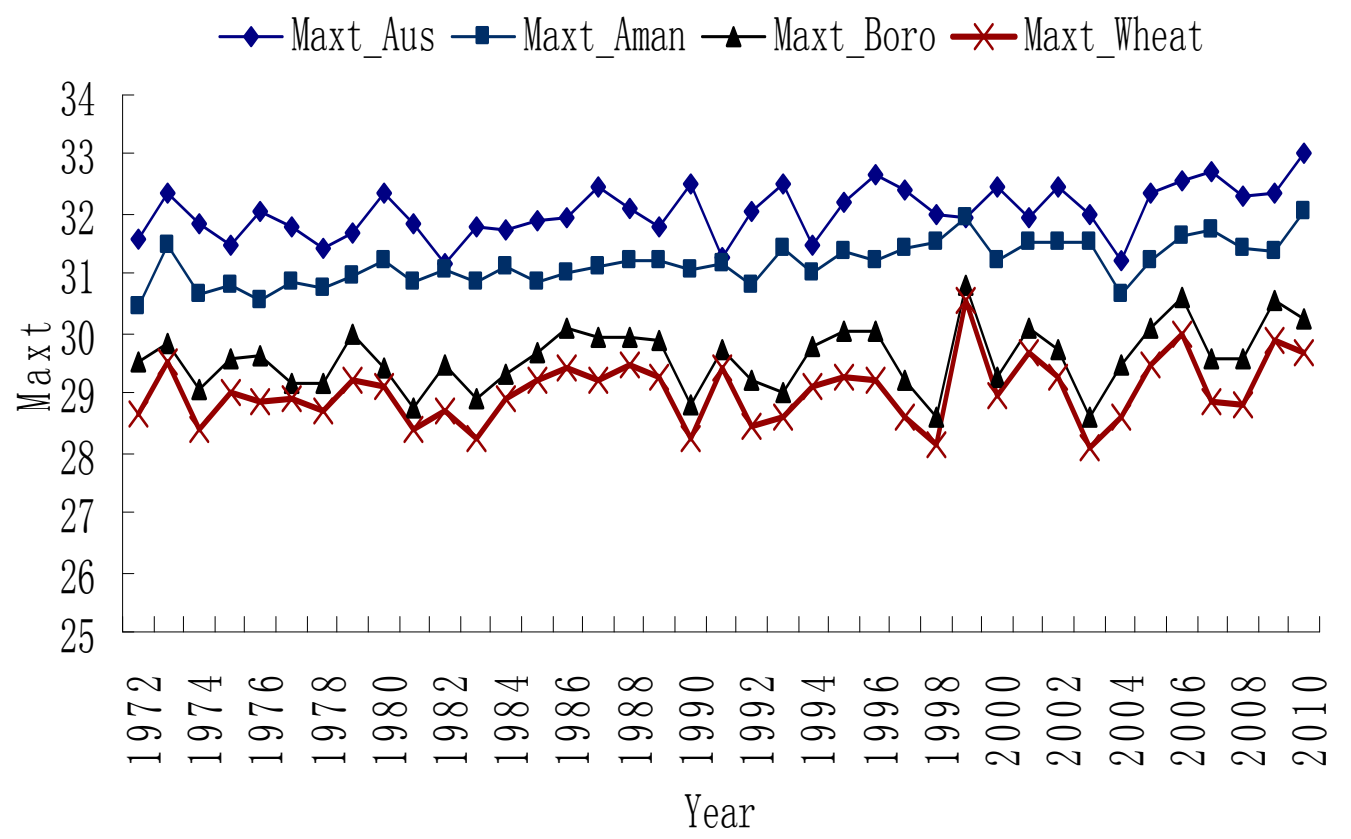

Figure 1. Graph showing the trends and variations in the average maximum temperature of Bangladesh, 1972-2010.

The trend of Mint

$\rightarrow$ Mint_Aus $\rightarrow$ Mint_Aman $\rightarrow$ Mint_Boro $\rightarrow$ Mint_Wheat

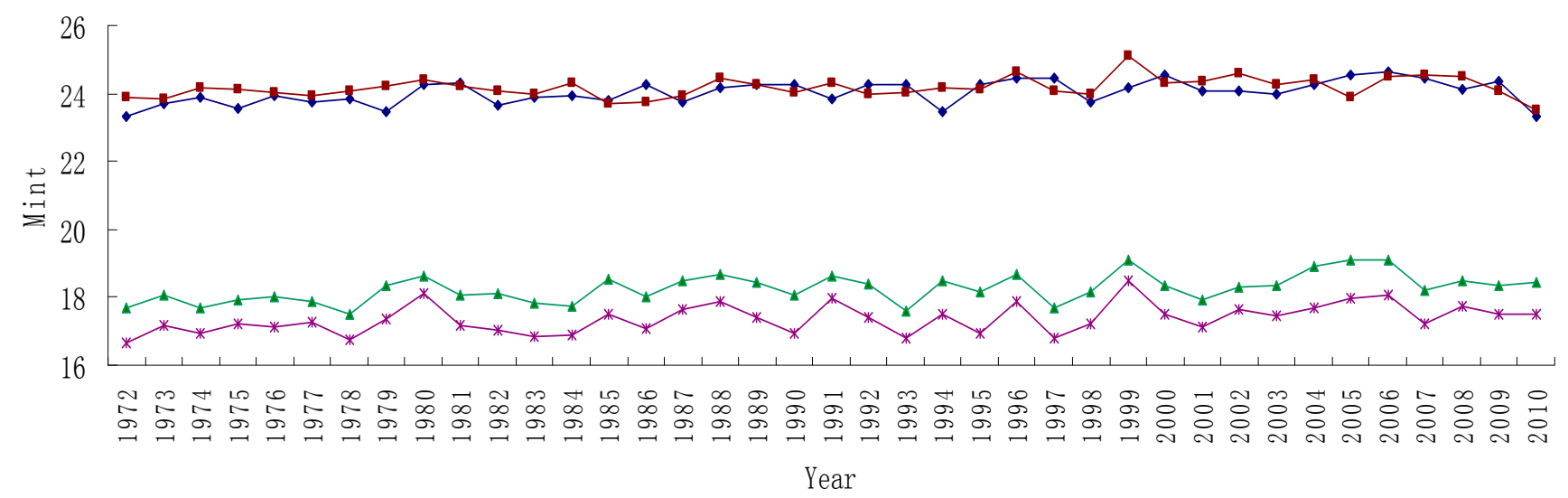

Figure 2. Graph showing the trends and variations in the average minimum temperature of Bangladesh, 1972-2010. 
The trend of Rainfall

$\rightarrow$ Rainfall_Aus $\rightarrow$-Rainfall_Aman $\rightarrow$ Rainfall_Boro $\rightarrow$ Rainfall_Wheat

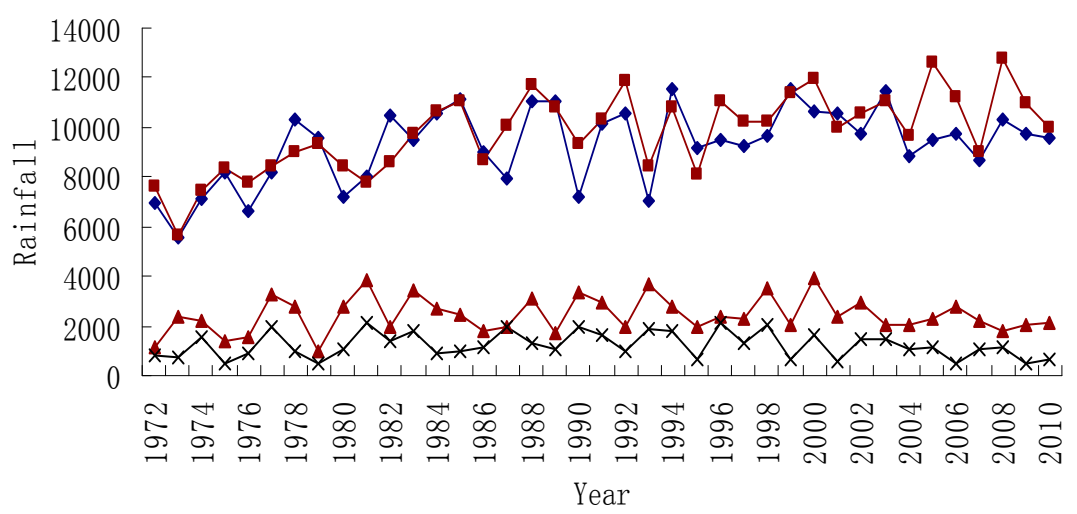

Figure 3. Graph showing the trends and variations in the total rainfall of Bangladesh, 1972-2010.

The trend of Humidity

$\rightarrow-$ Humidity_Aus $\rightarrow-$ Humidity_Aman $\rightarrow-$ Humidity_Boro $*$-Humidity_Wheat

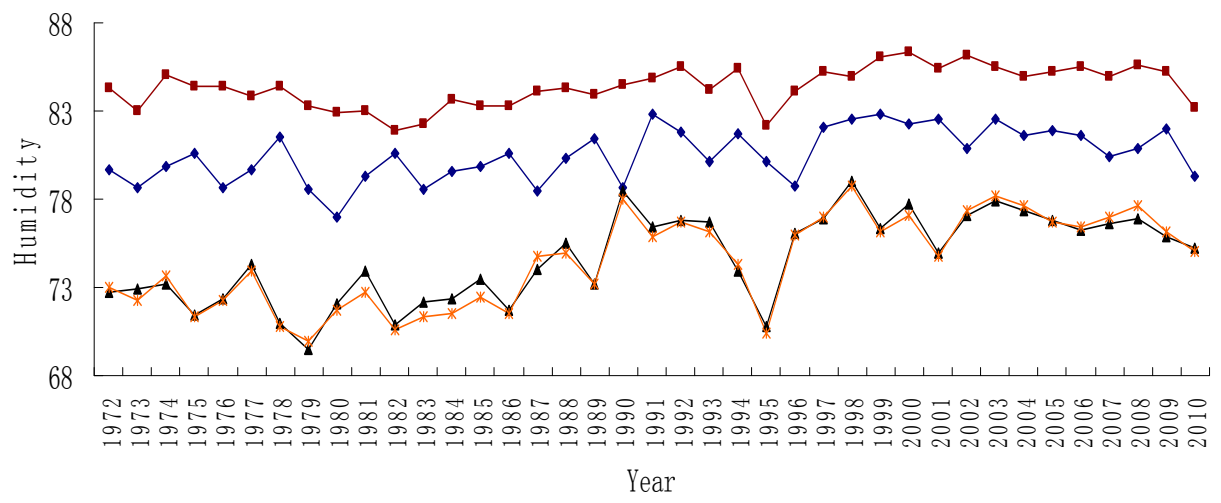

Figure 4. Graph showing the trends and variations in the average humidity of Bangladesh, 1972-2010.

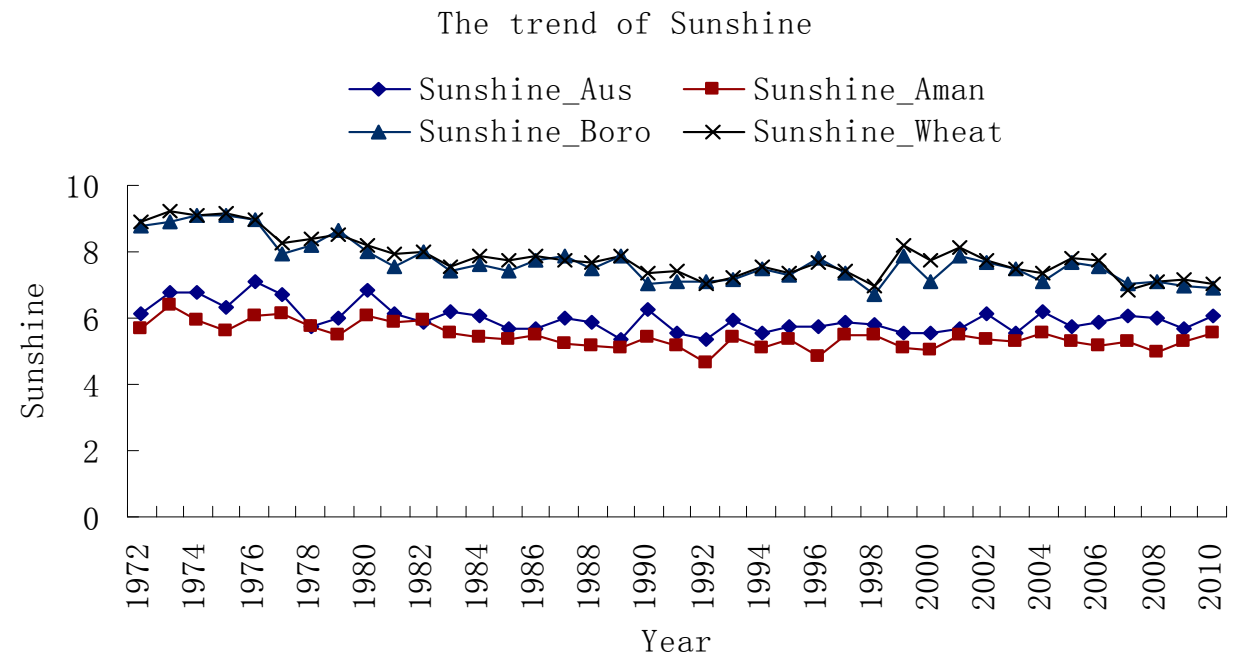

Figure 5. Graph showing the trends and variations in the average sunshine of Bangladesh, 1972-2010. 


\subsection{Non-Climatic Trend (Influence of Production Inputs) Removal in Crop Yields}

There are significant and positive trends between crop yields and time. The results of crop yield increases are largely from technique improvements, so the contributions of climate change are hard to identify from the raw yield data. Therefore, we need to remove the yield trend caused by non-climate factors (improved variety, management techniques, fertilizers, pesticides, etc.). There are five methods commonly used to remove its trend. Firstly, crop yields are regarded as a function of time, and yields are divided into two parts including trends and variations. The trend yields represent the yields of long-term periods of historical productivity, and the variation yields represent the yields impacted by climate. This linear regression method also receives larger absolute values of variation, known as heteroskedasticity, which violate some of the basic assumptions of linear regression. Secondly, in order to avoid heteroskedasticity in linear regression, log-transformation can transform absolute differences to relative differences. Thirdly, if crop yield trend changed by time is obvious with non-linear trend, higher order polynomials can be a choice in that case. Fourthly, another choice commonly used is first-differences to analyze time-series, that is, crop yield in this year subtracts the yield in the previous year. At the same time, climate data are also dealt with like this. This method can focus on year to year variation, so it can reduce the long-term trend of technical progress. Fifthly, adding time variables like year and year-squared in regression analysis is also a method considering technical improvements [35]. This study has paid attention to the fifth method. Accordingly, year (time variable) was included in the regression model to control the influence of technology advances in yield.

\subsection{Stationarity and Unit Root}

As the data series of this present study contained over 20 years of observations, this has enforced verifying for stationarity before executing the regression [36]. For determining the stationarity of a time series, a very popular formal method is the Augmented Dickey-Euller (ADF) test. Consequently, the augmented Dickey-Fuller (ADF) test was performed for all the time series to check the presence of unit roots [37] and the output was presented in Table 3. In view of dependent variables, the empirical results exposed that Aman rice and wheat yields have integrated of order $\mathrm{I}(0)$, thus, this series was stationary in their level form. However, Aus and Boro rice yields have integrated of order I(1), that indicated non-stationarity of this two data sets. In case of independent variables, humidity and sunshine showed integration of order I(1) for Boro rice and sunshine displayed integration of order I(1) for wheat, which have mentioned the presence of a unit root in the level data for Boro rice and wheat. However, the variables with I(1) were differenced first before computation [38,39].

Table 3. Augmented Dickey-Fuller (ADF) test for checking the stationarity of the data series.

\begin{tabular}{ccccc}
\hline Variables & $\begin{array}{c}\text { Integration of } \\
\text { Order for Aus }\end{array}$ & $\begin{array}{c}\text { Integration of Order } \\
\text { for Aman }\end{array}$ & $\begin{array}{c}\text { Integration of } \\
\text { order for Boro }\end{array}$ & $\begin{array}{c}\text { Integration of } \\
\text { Order for Wheat }\end{array}$ \\
\hline Yield & $\mathrm{I}(1)$ & $\mathrm{I}(0)$ & $\mathrm{I}(1)$ & $\mathrm{I}(0)$ \\
Maxt & $\mathrm{I}(0)$ & $\mathrm{I}(0)$ & $\mathrm{I}(0)$ & $\mathrm{I}(0)$ \\
Mint & $\mathrm{I}(0)$ & $\mathrm{I}(0)$ & $\mathrm{I}(0)$ & $\mathrm{I}(0)$ \\
Rainfall & $\mathrm{I}(0)$ & $\mathrm{I}(0)$ & $\mathrm{I}(0)$ & $\mathrm{I}(0)$ \\
Humidity & $\mathrm{I}(0)$ & $\mathrm{I}(0)$ & $\mathrm{I}(1)$ & $\mathrm{I}(0)$ \\
Sunshine & $\mathrm{I}(0)$ & $\mathrm{I}(0)$ & $\mathrm{I}(1)$ & $\mathrm{I}(1)$ \\
\hline
\end{tabular}




\subsection{Empirical Model Specification}

The dependent variable of this study was yield and cropping area of four major crops (such as Aus rice, Aman rice, Boro rice and wheat) and the independent variables included five climate variables (maximum temperature, minimum temperature, rainfall, humidity and sunshine). The major difference was that the growing season is different by crop, which is the most useful time for determining the impacts of climate change on the yield and cropping area of crops [40-42].

Multiple linear regression modeling was the guide to determine nexus between climate variables and crops yield as well as cropping area (harvested area) of different crops under the study. Based on the properties of dependent variables and inherent autocorrelation that existed among the independent variables, we came to the viewpoint that that Heteroskedasticity and Autocorrelation (HAC) consistent standard error and Feasible Generalized Least Square (FGLS) were the most suitable method compared to Ordinary Least Square (OLS) method [43-45]. Accordingly, the following format for regression modeling was used for the selected four major food crops.

$\mathrm{Y}_{\mathrm{it}} / \mathrm{CA}_{\mathrm{it}}=\alpha_{\mathrm{i} 0}+\alpha_{\mathrm{i} 1} \mathrm{Maxt}_{\mathrm{it}}+\alpha_{\mathrm{i} 2} \mathrm{Mint}_{\mathrm{it}}+\alpha_{\mathrm{i} 3}$ Rainfall $_{\mathrm{it}}+\alpha_{\mathrm{i} 4} \mathrm{Humidity}_{\mathrm{it}}+\alpha_{\mathrm{i} 5}$ Sunshine $_{\mathrm{it}}+\alpha_{\mathrm{i} 6} \mathrm{Year}_{\mathrm{it}}+\varepsilon_{\mathrm{it}}$

where, $\mathrm{Y}=$ yield $(\mathrm{kg} / \mathrm{acre})$ and $\mathrm{CA}=$ cropping area (in thousand hectares) of respective crop

$\mathrm{i}=1,2, \ldots . .4 ; 1$ means Aus rice, 2 means Aman rice, 3 means Boro rice and 4 means wheat

Maxt $=$ Growing season average daily maximum temperature $\left({ }^{\circ} \mathrm{C}\right)$

Mint $=$ Growing season average daily minimum temperature $\left({ }^{\circ} \mathrm{C}\right)$

Rainfall $=$ Growing season total daily rainfall $(\mathrm{mm})$

Humidity $=$ Growing season average daily humidity $(\%)$

Sunshine $=$ Growing season average daily sunshine (hours/day)

$\mathrm{t}=$ time (year)

$\varepsilon=$ Error term

In each case, the a priori expectation is that the crops that we grow for food need specific conditions to survive, such as the optimum temperature, soil moisture (water), atmospheric humidity and sunshine. A changing climate could have both beneficial and harmful effects on crops. Maximum and minimum temperature benefits crop production by enhancing photosynthesis thereby increasing crop yield as it increases [46]. However, extremely high temperature differentially affects the tremendous metabolic processes of plants, including the stability of various proteins and membranes and the effectiveness of enzymatic reactions in the cell which causes denaturation and finally metabolic imbalance. Higher temperature shock also leads to a reduction in photosynthetic rates by affecting photosystem II and Rubisco function and thereby inhibiting crops yield [47]. On the other hand, very low temperature may cause chilling injury in plants [48]. Precipitation increase affects crop yield positively by readily dissolving the nutrients for easy soil absorption by plants $[49,50]$. Unfortunately, intense rainfall during the monsoon season can also lead to soil erosion or the wash-out of surface soil and the depletion of plant nutrients in soil due to runoff. Destructive floods may devastate crops and leave farmers with no food to thrive and sell. Similarly, farmers can suffer production losses as a result of the insufficient and erratic precipitation during the rainy season [51]. 
Very high or very low relative humidity is not beneficial for higher grain yield. Crops tend absorb soil nutrients for optimum yield when there is sufficient humid air. Relative humidity directly controls the plant-water relationships and indirectly influences leaf growth, photosynthetic rates, pollination, occurrence of diseases and ultimately crop yields. Moreover, atmospheric dryness can seriously threaten dry matter production through stomatal control and leaf water potential [52]. Solar radiation (sunshine) directly affects crop growth and flowering by inducing photosynthesis. Plants are dependent on solar radiation to generate food, complete their life cycle and ease healthy growth and development. In contrast, excessive sunshine shows similar negative effects on crops, like higher temperature stress [53]. Thus, changes in climate would be likely to have various significant impacts on crops.

\section{Results and Discussion}

\subsection{The Regression Results for Aus Rice}

The HAC method was administered to identify the climate change impacts on the yield and cropping area of Aus rice. The findings are presented in Table 4, which revealed that climate variables affected the cropping area more than yield.

Table 4. The regression results of different rice crops and wheat.

\begin{tabular}{|c|c|c|c|c|c|c|c|c|}
\hline \multirow{2}{*}{$\begin{array}{c}\text { Independent } \\
\text { Variables } \\
\end{array}$} & \multicolumn{2}{|c|}{ Aus Rice } & \multicolumn{2}{|c|}{ Aman Rice } & \multicolumn{2}{|c|}{ Boro Rice } & \multicolumn{2}{|c|}{ Wheat } \\
\hline & Yield & C.Area & Yield & C.Area & Yield & C.Area & Yield & C.Area \\
\hline Maxt & $\begin{array}{l}13.38 \\
(1.27) \\
\end{array}$ & $\begin{array}{l}-157.5 \\
(-1.87) \\
\end{array}$ & $\begin{array}{l}-46.69 * \\
(-2.69) \\
\end{array}$ & $\begin{array}{l}-157.4 \\
(-0.93) \\
\end{array}$ & $\begin{array}{l}-40.61 \text { * } \\
(-2.37)\end{array}$ & $\begin{array}{l}-36.89 \\
(-0.53) \\
\end{array}$ & $\begin{array}{l}-74.55 * \\
(-2.35) \\
\end{array}$ & $\begin{array}{l}-23.09 \\
(-0.67) \\
\end{array}$ \\
\hline Mint & $\begin{array}{l}21.59 \\
(1.36) \\
\end{array}$ & $\begin{array}{l}157.8 \\
(1.05) \\
\end{array}$ & $\begin{array}{l}-30.19 \\
(-1.72) \\
\end{array}$ & $\begin{array}{l}-325.3 \\
(-1.86) \\
\end{array}$ & $\begin{array}{l}54.15 * \\
(2.17) \\
\end{array}$ & $\begin{array}{l}39.24 \\
(0.53) \\
\end{array}$ & $\begin{array}{l}40.24 \\
(1.27) \\
\end{array}$ & $\begin{array}{l}59.53 \\
(1.64) \\
\end{array}$ \\
\hline Rainfall & $\begin{array}{l}-0.01 \\
(-1.13) \\
\end{array}$ & $\begin{array}{c}0.135 * * \\
(3.44) \\
\end{array}$ & $\begin{array}{l}-0.02 * * \\
(-2.92) \\
\end{array}$ & $\begin{array}{c}-0.162 * * \\
(-2.84)\end{array}$ & $\begin{array}{c}0.01 \\
(0.65) \\
\end{array}$ & $\begin{array}{c}0.01 \\
(0.35) \\
\end{array}$ & $\begin{array}{c}0.01 \\
(0.27) \\
\end{array}$ & $\begin{array}{c}0.02 \\
(0.71) \\
\end{array}$ \\
\hline Humidity & $\begin{array}{l}10.75 * \\
(2.16)\end{array}$ & $\begin{array}{c}-135.6 * * \\
(-3.14)\end{array}$ & $\begin{array}{l}18.83 * \\
(2.70)\end{array}$ & $\begin{array}{l}145.1 \\
(2.00) \\
\end{array}$ & $\begin{array}{l}4.869 \\
(1.62) \\
\end{array}$ & $\begin{array}{l}-9.42 \\
(-0.43)\end{array}$ & $\begin{array}{l}-17.45 \\
(-1.73)\end{array}$ & $\begin{array}{l}-1.95 \\
(-0.24) \\
\end{array}$ \\
\hline Sunshine & $\begin{array}{c}0.04 \\
(0.00) \\
\end{array}$ & $\begin{array}{l}93.72 \\
(0.51)\end{array}$ & $\begin{array}{l}-3.12 \\
(-0.12)\end{array}$ & $\begin{array}{l}-137.2 \\
(-0.51) \\
\end{array}$ & $\begin{array}{l}41.87 \text { * } \\
(2.22)\end{array}$ & $\begin{array}{l}162.4 \\
(1.77)\end{array}$ & $\begin{array}{l}22.32 \\
(0.89) \\
\end{array}$ & $\begin{array}{r}5.80 \\
(0.18) \\
\end{array}$ \\
\hline Trend & $\begin{array}{c}-0.67 \\
(-1.38) \\
\end{array}$ & $\begin{array}{c}-70.54 * * * \\
(-16.67) \\
\end{array}$ & $\begin{array}{c}13.15 * * * \\
(12.90) \\
\end{array}$ & $\begin{array}{l}-8.786 \\
(-0.69) \\
\end{array}$ & $\begin{array}{r}0.47 \\
(0.47) \\
\end{array}$ & $\begin{array}{c}126.5 * * * \\
(11.58) \\
\end{array}$ & $\begin{array}{c}15.68 * * \\
(3.46) \\
\end{array}$ & $\begin{array}{l}-2.35 \\
(-1.31) \\
\end{array}$ \\
\hline Intercept & $\begin{array}{l}-406.4 \\
(-0.42) \\
\end{array}$ & $\begin{array}{c}152,962.7 * * * \\
(24.13) \\
\end{array}$ & $\begin{array}{c}-24,777.7 * * * \\
(-13.37) \\
\end{array}$ & $\begin{array}{c}26151.8 \\
(1.09) \\
\end{array}$ & $\begin{array}{l}-721.7 \\
(-0.44) \\
\end{array}$ & $\begin{array}{c}-249,739.1 * * * \\
(-11.88) \\
\end{array}$ & $\begin{array}{c}-27,733.7 * * \\
(-3.14) \\
\end{array}$ & $\begin{array}{l}4443.1 \\
(1.46) \\
\end{array}$ \\
\hline Model $\mathrm{R}^{2}$ & 0.25 & 0.95 & 0.87 & 0.38 & 0.30 & 0.85 & 0.05 & 0.23 \\
\hline Adjusted $\mathrm{R}^{2}$ & 0.10 & 0.94 & 0.84 & 0.26 & 0.16 & 0.82 & 0.14 & 0.10 \\
\hline
\end{tabular}

$*, * *$ and $* * *$ represents the $10 \%, 5 \%$ and $1 \%$ level of significance respectively. Figure in the parenthesis indicates "T-value". C. Area = Cropping Area.

The results further indicated that the effects of climate change on cropping area differed from the effects of climate change on the yield of Aus rice. In both the cases, humidity showed statistically significant influence. Surprisingly, the contribution was found to be positive for yield but negative for cropping area. Similarly, maximum temperature also displayed positive effect on yield and negative 
for cropping area, but the effect was statistically not significant for both the cases. Contrastingly, while rainfall very insignificantly affected the yield, it showed statistically significant and positive influence on the cropping area. Finally, minimum temperature and sunshine expressed positive influence on the yield and cropping area of Aus rice, although the effects were not significant. The adjusted $\mathrm{R}^{2}$ value implied that $10 \%$ of the yield variation and $94 \%$ of the variation in cropping area of Aus rice is influenced by the climatic variability and change.

\subsection{The Regression Results for Aman Rice}

FGLS method was employed to find out the influence of the climatic variables to the yield and cropping area of Aman rice. The results were presented in Table 4 which demonstrated that the effects of all the climatic parameters except humidity were observed to be detrimental for the yield and cropping area of Aman rice. The yield and cropping area are both negatively affected by the rainfall at the 5\% significance level. Similarly, both maximum and minimum temperature and sunshine also negatively contributed to the yield and cropping area of this crop, although only maximum temperature showed statistically significant influence on the yield at the $10 \%$ level. For both the cases (yield and cropping area), humidity contributed positively with a statistically significant effect on yield. It is obviously true that Aman rice grows in monsoon (rainy) season with relatively higher atmospheric humidity than other cropping seasons. However, the adjusted $\mathrm{R}^{2}$ value expressed that $84 \%$ variability in yield and $26 \%$ variability in cropping area of Aman rice is explained by the climatic factors, which strongly justified the climatic influence on this crop. Therefore, we can conclude that temperature extremes, intense rainfall and excessive sunshine all disastrously affected this major crop.

Findings of the present study are also justified by the past study that $1{ }^{\circ} \mathrm{C}$ increase in maximum temperature at vegetative, reproductive and ripening causes a decrease in Aman rice production by 2.94, 53.06 and 17.28 tons respectively. This past study also stated that a $1 \mathrm{~mm}$ increase in rainfall at vegetative, reproductive and ripening stages decrease Aman rice production by $0.036,0.230$ and 0.292 ton respectively [54].

\subsection{The Regression Results for Boro Rice}

Boro rice is cultivated in Bangladesh using irrigation facilities during the dry season. The HAC method was performed to determine the climate-Boro rice relationship and the findings were presented in Table 4. Results showed that, while the contribution of maximum temperature was found to be negative, four other climate variables greatly favored the yield of this crop. However, maximum temperature, minimum temperature and sunshine displayed statistically significant correlation with the yield of Boro rice at the $10 \%$ level of statistical significance. In contrast, none of the climatic variables showed statistically significant contribution to the cropping area of Boro rice. While maximum temperature and humidity insignificantly affected the cropping area of this crop, the other three variables (minimum temperature, rainfall and sunshine) positively influenced the same. The Adjusted $R^{2}$ value indicated that $16 \%$ variation in Boro rice yield and $82 \%$ variation in cropping area are explained by the climatic parameters. 
Interestingly, similar findings were found for all the climatic variables in both situations (yield and cropping area) but not for humidity. Therefore, it is clear that temperature climbing above the requirement seriously affected Boro rice yield in Bangladesh.

\subsection{The Regression Results for Wheat}

Wheat is grown in Bangladesh during the winter season, mostly under rain-fed conditions. The contribution of the climate variables obtained from FGLS method was presented in Table 4. Results indicated that maximum temperature and humidity showed adverse effects on the yield and cropping area of wheat, although the influence was statistically significant only for maximum temperature and only for the yield. Experimental evidence further showed that minimum temperature, rainfall and sunshine positively influenced the crop (in terms of yield and cropping area), though the relation was not statistically significant. More surprisingly, the direction of climatic influence for all the climatic variables was observed to be similar to the yield and cropping area of this crop. The adjusted $R^{2}$ value showed that $14 \%$ variation of yield and $10 \%$ variation of cropping area of wheat are explained by climate change and vulnerabilities in Bangladesh.

The $t$-value revealed that the contribution of maximum temperature to the yield was significant at the $10 \%$ level. However, this indicated the harmful impact of maximum temperature to the yield of wheat. The literature review also explored the same justification that high temperature is one of the major abiotic stresses that have adverse effects on growth, development and ultimately yield of wheat. At some specific stages of the life cycle of wheat, even a minute increase in temperature may lead to a total loss of crop yield [47].

Finally, we can say that, although different crops responded differently to the climate variables, among the four major crops, Aman rice, which is the number one major crop of Bangladesh in view of cropping area and production (see Table 1) was found to be more vulnerable to climate change effects compared to the other three major crops.

\section{Conclusions}

The utmost effort of this study was to examine the impacts of climate change on the yield and cropping area of major food crops in Bangladesh. The HAC and FGLS methods were applied to satisfy the objective. Results indicated that cropping area of Aus rice was influenced greatly by the climatic variations compared to the yield of this crop. The most influential climatic variables for Aman rice production in Bangladesh were observed to be maximum temperature and rainfall. The findings confirmed that temperature (both maximum and minimum) and rainfall increases beyond their optimum requirement may be devastating to the yield and cropping area of Aman rice. In contrast, humidity positively influenced the yield and cropping area of Aman rice and this is justifiable because this crop grows in moist (humid) conditions during the monsoon months. The influence of maximum temperature was also observed to be detrimental for Boro rice and wheat. However, minimum temperature and sunshine exposed positive interrelation with Boro rice and wheat in respect of both yield and cropping area with statistically significant contribution to Boro rice yield only. Output further indicated that while humidity insignificantly favored the yield, it also insignificantly affected the cropping area of Boro rice. Similar to the effect of maximum temperature, the effect of excessive 
humidity was also shown to be undesirable for wheat cultivation, though this was not statistically significant. However, the empirical evidence established strong credibility that, overall, climate variability and change adversely impacted yield and cropping area of major food crops in Bangladesh. Similarly, the concerned body thus should take proper initiative to combat against climate change impacts on agriculture in the country for ensuring food security for the ever increasing population through implementing sustainable agricultural development. To summarize, national level data might not depict the true scenario for the different agro-ecological zones of any country about climate change impacts on crops yield [55]. Therefore, region-specific research should be conducted to highlight regional differences and to guide intensive measures on the perspective of climate change and cultivation of major food crops in Bangladesh.

\section{Acknowledgments}

The first author wishes to acknowledge Chinese Scholarship Council (CSC), Government of China, for providing financial support for the postgraduate studies in China. Moreover, this work is supported by the National Natural Science Foundation of China (Program No. 71273105 and 41371520).

\section{Author Contributions}

Data collection, experimental designing and data analysis were done by Md. Ruhul Amin. The results interpretation and English editing were done by Junbiao Zhang and Mingmei Yang.

\section{Conflicts of Interest}

The authors declare no conflicts of interest.

\section{References and Notes}

1. Hossain, A.; Teixeira da Silva, J.A. Phenology, Growth and Yield of Three Wheat (Triticum. aestivum L.) Varieties As Affected by High Temperature Stress. Not. Sci. Biol. 2013, 4, 97-106.

2. Ferdous, M.G.; Baten, M.A. Climatic Variables of 50 Years and their Trends over Rajshahi and Rangpur Division. J. Environ. Sci. Nat. Res. 2011, 4, 147-150.

3. Ahmed, A.; Ryosuke, S. Climate Change and Agricultural Food Production of Bangladesh: An Impact Assessment Using GIS-Based Biophysical Crop. Simulation Model; Center for Spatial Information Science, University of Tokyo: Komaba, Japan, 2000.

4. Rahman, M.W.; Parvin, L. Impact of Irrigation on Food Security in Bangladesh for the Past Three Decades. J. Water Res. Prot. 2009, 3, 216-225.

5. Ahmed, A.U.; Haque, N. Climate Change and Sustainable Development. In Proceedings of the Dhaka Meet on Sustainable Development, Citizens' Perspectives on Sustainable Development, Bangladesh Unnayan Parishad (BUP), Dhaka, Bangladesh, 14-18 March 2002.

6. Sarker, M.A.R.; Alam, K.; Gow, J. Exploring the Relationship between Climate Change and Rice Yield in Bangladesh: An Analysis of Time Series Data. Agric. Sys. 2012, 112, 11-16. 
7. Agrawala, S.T.O.; Ahmed, A.U.; Smith, J.; Aalst, M.V. Development and Climate Change in Bangladesh: Focus on Coastal Flooding and the Sunderbans; Organisation for Economic Co-operation and Development (OECD): Paris, France, 2003.

8. Ahmed, A.U. Bangladesh Climate Change Impacts and Vulnerability. A Synthesis; Climate Change Cell, Department of Environment, CDMP, Government of the People's Republic of Bangladesh, Dhaka, Bangladesh, 2006.

9. Food and Agriculture Organization (FAO). Climate Variability and Change: Adaptation to Drought in Bangladesh. In A Resource Book and Training Guide; FAO: Rome, Italy, 2007.

10. Mirza, M.M.Q. Modeling the Effects of Climate Change on Flooding in Bangladesh. Ph.D. Thesis, International Global Change Institute (IGCI), University of Waikato, Hamilton, New Zealand, 1997.

11. Ahmed, A.U.; Alam, M. Development of Climate Change Scenarios With General Circulation Models. In Vulnerability and Adaptation to Climate Change for Bangladesh; Huq, S., Karim, Z., Asaduzzaman, M., Mahtab, F., Eds.; Kluwer Academic Publishers: Dordrecht, The Netherlands, 1998; pp. 13-20.

12. Government of Bangladesh (GOB) and United Nations Development Program (UNDP). The Probable Impacts of Climate Change on Poverty and Economic Growth and Options of Coping with Adverse Effects of Climate Change in Bangladesh. Policy Study, Dhaka, Bangladesh, 2009.

13. Bangladesh Bureau of Statistics (BBS). Compendium of Environment Statistics of Bangladesh. Government of Bangladesh, Dhaka, Bangladesh, 2005.

14. Intergovernmental Panel on Climate Change (IPCC). Climate Change: Impacts, Adaptation and Vulnerability. In Contribution of Working Group II to the Fourth Assessment Report of the Intergovernmental Panel on Climate Change; Cambridge University Press: Cambridge, UK, 2007.

15. Begum, M.E.A.; D'Haese, L. Supply and Demand Situations for Major Crops and Food Items in Bangladesh. J. Ban. Agric. Univ. 2010, 8, 91-102.

16. Basak, J.K.; Ali, M.A.; Islam, M.N.; Alam, M.J.B. Assessment of the Effect of Climate Change on Boro Rice Production in Bangladesh Using CERES-Rice Model. In Proceedings of the International Conference on Climate Change Impacts and Adaptation Strategies for Bangladesh, 18-20 February 2009; pp. 103-113.

17. Amin, M.G.M.; Ali, M.H.; Islam, A.K.M.R. Agro-Climatic Analysis for Crop Planning in Bangladesh. Ban. J. Agric. Eng. 2004, 15, 1-40.

18. Moorthy, A.; Buermann, W.; Rajagopal, D. The Impact of Climate Change on Crop Yields in India from 1961 to 2010. Available online: http://www.environment.ucla.edu/media/files/ 3-Climate-Change-and-Crop-Yields-in-India-\%282\%29-54-ylq.pdf (accessed on 8 May 2014)

19. Zhang, Y.Q.; Cai, Y.X.; Beach, R.H.; McCarl, B.A. Modeling Climate Change Impacts on the US Agricultural Exports. J. Integr. Agric. 2014, 13, 666-676.

20. Kurukulasuriya, P.; Ajwad, M.I. Application of the Ricardian Technique to Estimate the Impact of Climate Change on Smallholder Farming in Sri Lanka. Clim. Chang. 2007, 81, 39-59.

21. Kabubo-Mariara, J.K.; Karanja, F.K. The Economic Impact of Climate Change on Kenyan Crop Agriculture: A Ricardian Approach. Glob. Planet. Chang. 2007, 57, 319-330. 
22. Haim, D.; Shechter, M.; Berliner, P. Assessing the Impact of Climate Change on Representative Field Crops in Israel Agriculture: A Case Study of Wheat and Cotton. Clim. Chang. 2008, 86, 425-440.

23. Deressa, T.T.; Hassan, R.M. Economic Impact of Climate Change on Crop Production in Ethiopia: Evidence from Cross-Section Measures. J. Afr. Econ. 2009, 18, 529-554.

24. Wang, J.; Mendelsohn, R.; Dinar, A.; Huang, J.; Rozelle, S.; Zhang, L. The Impact of Climate Change on China's Agriculture. Agric. Econ. 2009, 40, 323-337.

25. Mendelsohn, R. The Impact of Climate Change on Agriculture in ASIA. J. Integr. Agric. 2014, 13, 660-665.

26. Rashid, M.H.; Islam, M.S. Adaptation to Climate Change for Sustainable Development of Bangladesh Agriculture. In Proceedings of the 3rd session of Technical Committee of Asian and Pacific Center for Agricultural Engineering and Machinery (APCAEM), Beijing, China, 20-21 November 2007.

27. Rimi, R.H.; Rahman, S.H.; Karmakar, S.; Hussain, S.G. Trend Analysis of Climate Change and Investigation on its Probable Impacts on Rice Production at Sathkhira, Bangladesh. Pak. J. Meteorol. 2009, 6, 37-50.

28. Awal, M.A.; Siddique, M.A.B. Rice Production in Bangladesh Employing by ARIMA Model. Ban. J. Agric. Res. 2011, 36, 51-62.

29. Sarker, M.A.R. Impacts of Climate Change on Rice Production and Farmers' Adaptation in Bangladesh. Ph.D. Thesis, University of Southern Queensland, Toowoomba, Australia, 2012.

30. Government of Bangladesh (GOB). Yearbook of Agricultural Statistics of Bangladesh; Ministry of Planning: Dhaka, Bangladesh, 2009.

31. Rahman, M.A.; Islam, S.M.R. Climate Change Observed in the Barindtrack. The Experiment 2014, 21, 1499-1502.

32. Mahmood, R. Impacts of Air Temperature Variations on the Boro Rice Phenology in Bangladesh: Implications for Irrigation Requirements. Agric. For. Meteorol. 1997, 84, 233-247.

33. Government of Bangladesh (GOB). Yearbook of Agricultural Statistics of Bangladesh; Ministry of Planning: Dhaka, Bangladesh, 2012.

34. Bangladesh Meteorological Department (BMD). Data Collected from BMD Headquarter at Dhaka (Climate Section), Bangladesh on 15 December 2013.

35. Wenjiao, S.; Fulu, T.; Zhang, Z. A Review on Statistical Models for Identifying Climate Contributions to Crop Yields. J. Geogr. Sci. 2013, 23, 567-576.

36. Chen, C.; McCarl, B.A.; Schimmelpfennig, D.E. Yield Variability as Influenced by Climate: A Statistical Investigation. Clim. Chang. 2004, 66, 239-261.

37. Dickey, D.A.; Fuller, W.A. Distribution of the Estimators for Autoregressive Time Series with a Unit Root. J. Amer. Stat. Soc. 1979, 75, 427-431.

38. Gujrati, D. Basic Econometrics, 4th ed; The McGraw-Hill: New York, NY, USA, 2004.

39. McCarl, B.A.; Villavicencio, X.; Wu, X. Climate Change and Future Analysis: Is Stationarity Dying? Amer. J. Agric. Econ. 2008, 90, 1241-1247.

40. Iizumi, T.; Ramankutty, N. How do weather and climate influence cropping area and intensity? Glob. Food Secur. 2014, doi:10.1016/j.gfs.2014.11.003. 
41. Lobell, D.B.; Burke, M.B.; Tebaldi, C.; Mastrandrea, M.D.; Falcon, W.P.; Naylor, R.L. Prioritizing Climate Change Adaptation Needs for Food Security in 2030. Science 2008, 319 , 607-610.

42. Lobell, D.B.; Field, C.B. Global Scale Climate-Crop Yield Relationships and the Impacts of Recent Warming. Environ. Res. Let. 2007, 2, 1-7.

43. Cochrane, D.; Orcutt, G. Application of Least Square Regression to Relationships Containing Autocorrelated Error Terms. J. Amer. Stat. Assoc. 1949, 44, 32-61.

44. Prais, S.; Winsten, C. Trend Estimation and Serial Correlation; Cowles Commission Discussion Paper No. 383; Cowles Commission: Chicago, IL, USA, 1954.

45. Newey, W.; West, K. A Simple Positive Semi-Definite, Heteroskedasticity and Autocorrelation Consistent Covariance Matrix. Econometrica 1987, 55, 703-708.

46. Sombroek, W.G.; Gommes, R. The Climate Change Agriculture Conundrum: Global Climate Change and Agricultural Production. Direct and Indirect Effects. In FAO Corporate Document Repository; Available online: http://www.fao.orgldocrep/w5183E/w5183e03.htm\#1\%20the\% 20climate (accessed on 10 May 2014).

47. Mathur, S.; Jajoo, A. Effects of Heat Stress on Growth and Crop Yield of Wheat (Triticum aestivum). Available online: http://link.springer.com/chapter/10.1007/978-1-4614-8591-9_8 (accessed on 21 December 2014).

48. Bhandari, K.; Nayyar, H. Low Temperature Stress in Plants: An Overview of Roles of Cryoprotectants in Defense. Available online: http://link.springer.com/chapter/10.1007/978-14614-8591-9_9 (accessed on 21 December 2014).

49. Intergovernmental Panel on Climate Change (IPCC). Climate Change 2001: The Scientific Basis; Cambridge University Press: Cambridge, UK, 2001.

50. Intergovernmental Panel on Climate Change (IPCC). Climate Change 2001: Impacts, Vulnerability and Adaptation; Cambridge University Press: Cambridge, UK, 2001.

51. Lichtenstein, D. The Effects of the Rainy Season on Farmers. Available online: http://www.ehow.com/info_7996601_effects-rainy-season-farmers.html (accessed on 21 December 2014).

52. TNAU Agritech Portal. Agrometeorology: Relative Humidity and Plant Growth. Available online: http://agritech.tnau.ac.in/agriculture/agri_agrometeorology_relativehumidity.html (accessed on 22 December 2014).

53. Smestad, A. The Effect of Light on Plant Growth. Available online: http://www.ehow.com/ about_5251025_effect-light-plant-growth.html (accessed on 22 December 2014).

54. Ministry of Environment and Forest (MOEF). Bangladesh Climate change Strategy Action Plan; Government of the People Republic of Bangladesh: Dhaka, Bangladesh, 2009.

55. Lobell, D.B.; Cahill, K.N.; Field, C.B. Historical Effects of Temperature and Precipitation on California Crop Yields. Clim. Chang. 2007, 81, 187-203.

(C) 2015 by the authors; licensee MDPI, Basel, Switzerland. This article is an open access article distributed under the terms and conditions of the Creative Commons Attribution license (http://creativecommons.org/licenses/by/4.0/). 